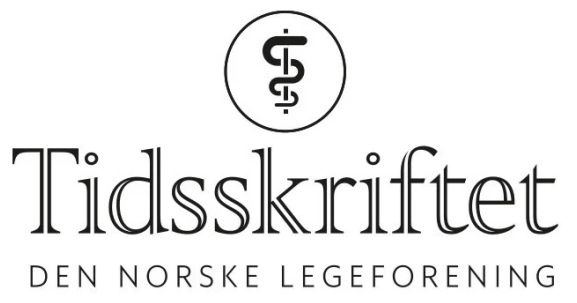

\title{
Bør pasienter med førstegangspsykose alltid få antipsykotika?
}

FRA ANDRE TIDSSKRIFTER

KETIL SLAGSTAD

Tidsskriftet

En studie viste at pasienter med førstegangspsykose klarte seg like godt med som uten antipsykotisk legemiddelbehandling. 


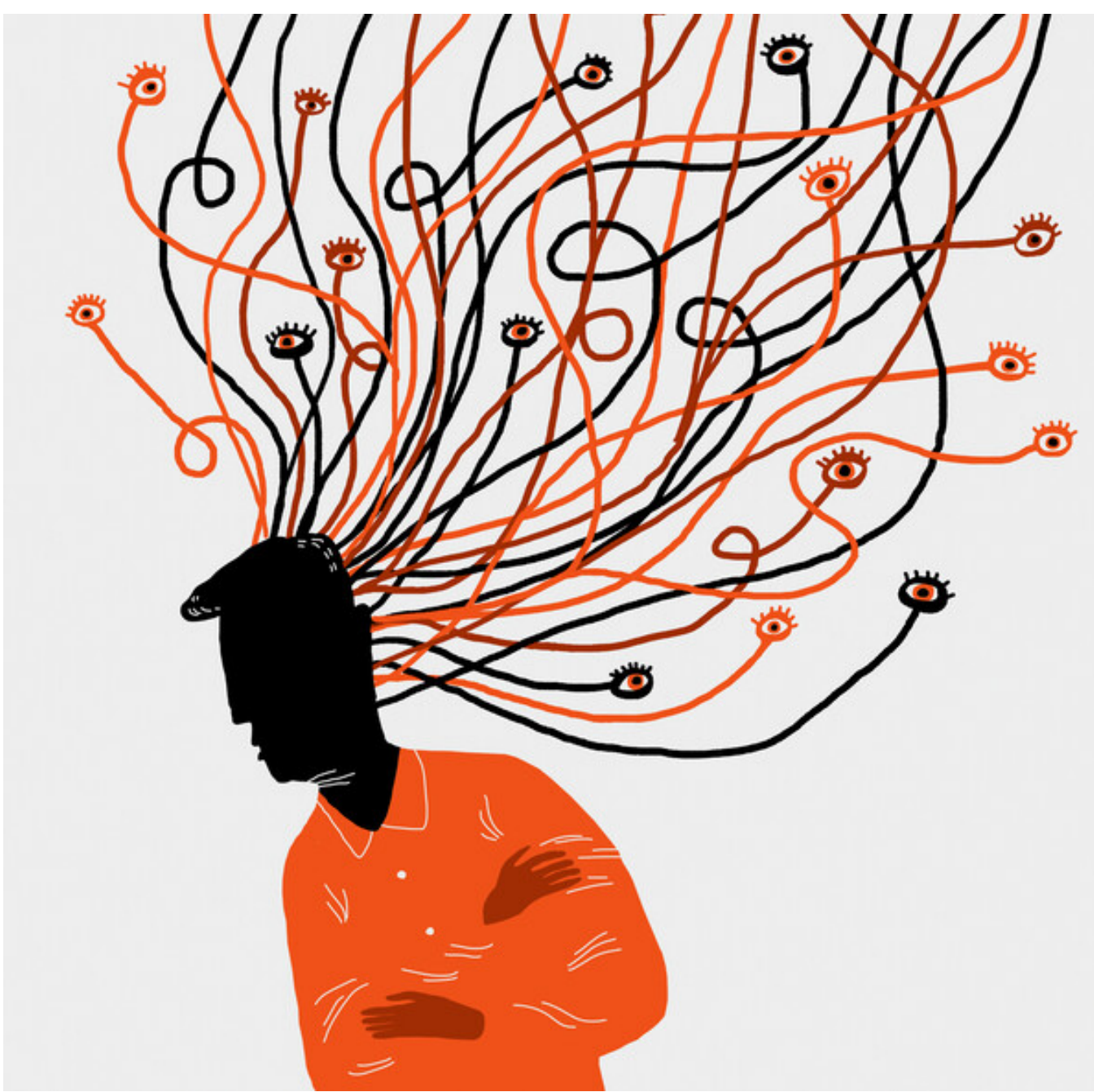

Illustrasjon: Oivind Hovland / Ikon Images

Antipsykotika har blitt brukt i behandling av psykoselidelser siden legemidlene først kom på markedet i 1950-årene, men det fantes inntil nylig ingen placebokontrollerte randomiserte studier av slik behandling hos pasienter med førstegangspsykose.

I en trippelblindet ikke-underlegenhetsstudie, publisert i tidsskriftet Schizophrenia Bulletin Open, ble 9o pasienter i aldersgruppen 15-25 år med førstegangspsykose randomisert til intensiv psykososial behandling med eller uten antipsykotika i lav dose (1․).

Inklusjonskriteriene var strenge, bl.a. samtykkekompetanse, psykosevarighet under seks måneder, stabile boforhold og lav risiko for å skade seg selv eller andre. Etter seks måneder var det ingen forskjell mellom gruppene, verken i symptomtrykk eller funksjonsnivå (SOFAS-skår, gjennomsnittlig forskjell -0,2, 95 \% KI -6,3-5,8). Etter ett og to år var det ingen signifikant forskjell mellom gruppene, men siden den valgte underlegenhetsmarginen var omfattet av konfidensintervallet, kunne man ikke trekke sikre slutninger.

- Dette er en viktig studie fordi dagens behandlingsanbefalinger er lite differensierte, og vi i liten grad vet om og når det er trygt å avvente medikamentell behandling, sier Erlend Gardsjord, som er overlege ved Seksjon for tidlig psykosebehandling ved Oslo universitetssykehus.

- Fagfolk har vært skeptiske til om studier som denne i det hele tatt kunne la seg gjennomføre av forsvarlighetshensyn, men denne studien viser at dette kan gjøres på en trygg måte, sier Gardsjord, som understreker at studien er liten og at studiepopulasjonen er selektert.

- Derfor har resultatene begrenset verdi for pasienter med psykoselidelser som gruppe, i tillegg til at langtidseffektene av å avvente oppstart med antipsykotika er usikre, sier Gardsjord, som håper at liknende, men større studier med lengre oppfølgingstid vil kunne føre til mer differensierte behandlingsanbefalinger for pasienter med førstegangspsykose. 
1. Francey SM, O'Donoghue B, Nelson B et al. Psychosocial intervention with or without antipsychotic medication for first-episode psychosis: A randomized noninferiority clinical trial. Schizophrenia Bulletin Open 2020; 1: sgaao15. [CrossRef]

Publisert: 16. september 2020. Tidsskr Nor Legeforen. DOI:10.4045/tidsskr.20.0621

(C) Tidsskrift for Den norske legeforening 2023. Lastet ned fra tidsskriftet.no 26. april 2023. 